УДК 621.352;544.6

В. А. Зуёк, Р. А. Рудь, М. В. Третьяков, Я. А. Куштым, В. С. Красноруцкий, Т. П. Черняева, В. М. Грицина

Научно-технический комплекс «Ядерный топливный цикл» Национального научного центра «Харьковский физикотехнический институт», г. Харьков, Украина

\section{Контактная коррозия}

\section{алюминия и его сплавов в водной среде ядерных установок}

\begin{abstract}
Исследованы процессы, происходящие при контактной коррозии таких конструкционных материалов ядерных установок, как алюми ний, его сплав САВ-1 с циркониевым сплавом Э110 и нержавеющей сталью марки Х18H10T. Результаты электрохимических и автоклавных испытаний исследуемых контактных пар показывают, что во всех случаях анодом является алюминий (или САВ-1), который окисляется более интенсивно по сравнению с Э110 и Х18Н10Т. При окислении алюминия и СAB-1 в водной среде продукты коррозии переходят в коррозионную среду. Предварительное окисление материала катода (Э110) до толщины оксидной пленки 1-1,5 мкм практически исключает гальваническую составляющую коррозии САВ-1 в контактной паре с Э110, что подтверждается результатами измерения плотности тока коррозии и другими показателями, характеризующими надежность работы элементов и безопасность всей установки в целом.
\end{abstract}

Ключевые слова: контактная коррозия, алюминий, CAB-1, Э110, нержавеющая сталь, ток коррозии

В. А. Зуйок, Р. О. Рудь, М. В. Трет'яков, Я. О. Куштим, В. С. Красноруцький, Т. П. Черняєва, В. М. Грицина

\section{Контактна корозія алюмінію та його сплавів у водному середовищі ядерних установок}

Досліджено процеси, що відбуваються в процесі контактної корозі таких конструкційних матеріалів ядерних установок, як алюміній, його сплав САВ-1 з цирконієвим сплавом E110 і нержавіючою сталлю марки Х18H10T. Результати електрохімічних та автоклавних випробувань досліджуваних контактних пар показують, що в усіх випадках анодом $\epsilon$ алюміній (або САВ-1), який окиснюється більш інтенсивно порівняно з E110 і X18H10T. У разі окиснювання алюмінію та CAB-1 у водному середовищі продукти корозії переходять у корозійне середовище Попереднє окиснення матеріалу катода (E110) до товщини оксидної плівки 1-1,5 мкм практично унеможливлюе гальванічну складову корозії САВ-1 у контактній парі з Е110, що підтверджується результатами вимірювання щільності струму корозії та іншими показниками, які характеризують надійність роботи елементів і безпеку всієї установки в цілому.

Ключові слова: контактна корозія, алюміній, CAB-1, E110, нержавіюча сталь, струм корозії.

() В.А. Зуёк, Р.А. Рудь, М.В. Третьяков, Я.А. Куштым В.С. Красноруцкий, Т.П. Черняева, В.М. Грицина, 2015
$\mathrm{Y}$

злы и детали ядерных установок наиболее часто выполняются из таких материалов, как нержавеющая сталь, циркониевые и алюминиевые сплавы. Применение этих материалов обусловлено приемлемыми ядерно-физическими и другими характеристиками, а также тем, что они хорошо изучены и апробированы при работе в различных типах ядерных установок, бассейнах выдержки и т. д. В то же время контакт таких разнородных материалов, как алюминий или его сплавы с нержавеющей сталью или циркониевым сплавом, может привести к возникновению контактной (гальванической) коррозии.

Если поместить два разнородных токопроводящих материала в электролит, между ними начинает протекать электрический ток, который называется током коррозии (гальваническим, анодным). Гальваническая коррозия представляет собой часть общего коррозионного процесса, протекающего на анодной стороне контактирующих материалов, и имеет непосредственную связь с током коррозии по закону Фарадея [1]. При образовании гальванической пары один из металлов становится анодом; скорость его коррозии увеличивается по сравнению со скоростью коррозии при отсутствии гальванопары. Скорость коррозии второго металла при этом замедляется [2].

При контакте алюминия или его сплавов с нержавеющей сталью в воде наблюдается значительное увеличение скорости коррозии анода (алюминия, алюминиевого сплава), скорость же коррозии нержавеющей стали изменяется незначительно [3].

В гальванической коррозии важную роль играет среда (в данном случае - чистота воды). Гальваническая коррозия алюминия имеет место в бассейнах выдержки и мокрых хранилищах отработавшего ядерного топлива, когда алюминий контактирует с нержавеющей сталью или алюминиевыми сплавами в воде с высокой электропроводностью более 100 мкСм/см [3, 4]. В средах, где алюминиевый сплав остается пассивным, допускается его контакт с нержавеющими сталями. В очень чистой воде (1-3 мкСм/см) гальванические эффекты не приводят к деградации эксплуатационной способности алюминиевых сплавов, за исключением щелевой коррозии при контакте металлов, которая способствует снижению водородного показателя и накоплению примесей в коррозионной среде щели [3].

Совместное применение алюминиевого и циркониевого сплавов в ядерной энергетике встречается реже. При их контакте коррозия сопровождается двумя явлениями: 1) увеличением скорости коррозии алюминиевого сплава; 2) катодным гидрированием циркониевого сплава [4].

Существует много доказательств того, что в случае катодной поляризации как в гальванических парах (при контакте), так и прилагаемом потенциале, сплавы циркония подвержены значительному гидрированию. Значительное гидрирование циркониевых труб наблюдалось в тех местах исследовательского реактора Hanford K-reactor, где алюминиевые решетки контактировали с циркониевыми трубами. Температура составляла около $90{ }^{\circ} \mathrm{C}$, а охладителем была вода из p. Columbia River [5].

Гидрирование циркониевого сплава в контакте с алюминием наблюдали в ходе экспериментов по изучению радиационного роста сплавов типа циркалой при низких температурах (около $50{ }^{\circ} \mathrm{C}$ ) в воде, которые проводились в реакторе ATR в Idaho Falls (США) [6].

Согласно имеющимся литературным данным, в случае контакта алюминия или его сплавов с другими металлами и сплавами в водной среде с высокой электрической проводимостью нужно электрически разделить разнородные материалы нетокопроводящим (изолирующим) 
материалом. Это не всегда возможно при использовании контактирующих материалов непосредственно в активной зоне ректора под облучением.

Цель данной работы - исследовать коррозию алюминия и его сплава CAB-1 в контакте с циркониевым сплавом Э110 и нержавеющей сталью 08Х18Н10Т в водной среде без применения изолирующих материалов; установить, какой из материалов будет оказывать минимальное негативное влияние на алюминий или его сплав при их контакте; определить условия, при которых использование данных контактных пар позволит минимизировать или полностью исключить гальваническую коррозию в водной среде ядерных установок.

\section{Материалы и методики исследования}

Образцы для исследований размером 9×35 мм вырезали из прутков алюминия технической чистоты, алюминиевого сплава САВ-1, нержавеющей стали 12X18Н10Т и циркониевого сплава Э110.

Для исследования контактной коррозии сплавов использовали стандартную методику погружения, которая подразумевает постоянный электрический контакт между двумя разнородными металлами, частично погруженными в электролит.

Значения потенциалов приведены по отношению к стандартному водородному электроду. Стационарные потенциалы образцов измеряли по отношению к хлорсеребряному электроду сравнения в $3 \%$ растворе $\mathrm{NaCl}$ при температуре $25{ }^{\circ} \mathrm{C}$. Для приготовления раствора использовали химически обессоленную воду с проводимостью 0,25 мкСм/см. Соотношение площадей поверхности контактирующих металлов и сплавов составляло 1:1.

Автоклавные коррозионные испытания проводили при атмосферном давлении в химически обессоленной воде с проводимостью 0,25 мкСм/см при температуре $50{ }^{\circ} \mathrm{C}$ и в воде с добавкой $\mathrm{NaCl}$ при $25{ }^{\circ} \mathrm{C}$. Водородный показатель $(\mathrm{pH})$ среды при комнатной температуре составлял 7,2. После каждого цикла испытаний образцы извлекали для взвешивания, коррозионную среду заменяли на свежеприготовленную, так как в течение испытаний проводимость ее увеличивалась почти на два порядка и на дне сосуда автоклава имелось незначительное количество коллоидного осадка.

\section{Результаты экспериментов}

Определение стационарных потенциалов исследуемых материалов в водном растворе $\mathrm{NaCl}$. При исследовании гальванической коррозии необходимо определить значение стационарного потенциала, так как именно он отражает склонность контактируемых металлов к гальванической коррозии. Значение стационарного потенциала зависит от вида материала (его химического состава), обработки поверхности и среды, в которой он определяется.

В начальный момент погружения материалов в 3 \% водный раствор $\mathrm{NaCl}$ стационарный потенциал как CAB-1, так и Х18Н10T более отрицательный. Через 1-3 мин его значение возрастает до стационарного и при дальнейшей выдержке в данных условиях меняется слабо (рис. 1).

В случае контакта сплава САВ-1 и стали Х18Н10Т их потенциалы благодаря поляризации сближаются, а ток

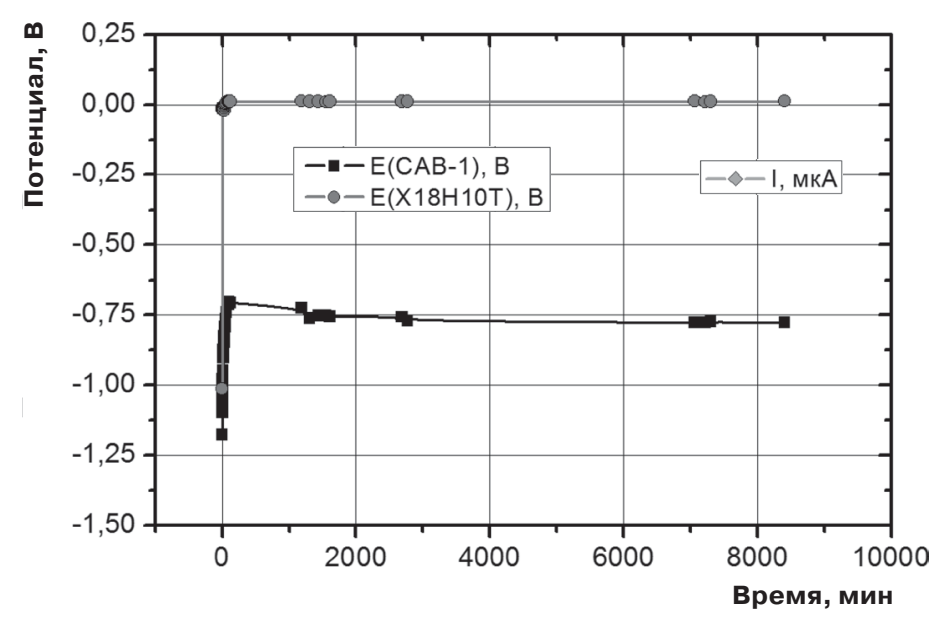

Рис. 1. Зависимость потенциалов САВ-1 и Х18Н10Т от времени испытания в $3 \%$ растворе $\mathrm{NaCl}$ при $25^{\circ} \mathrm{C}$

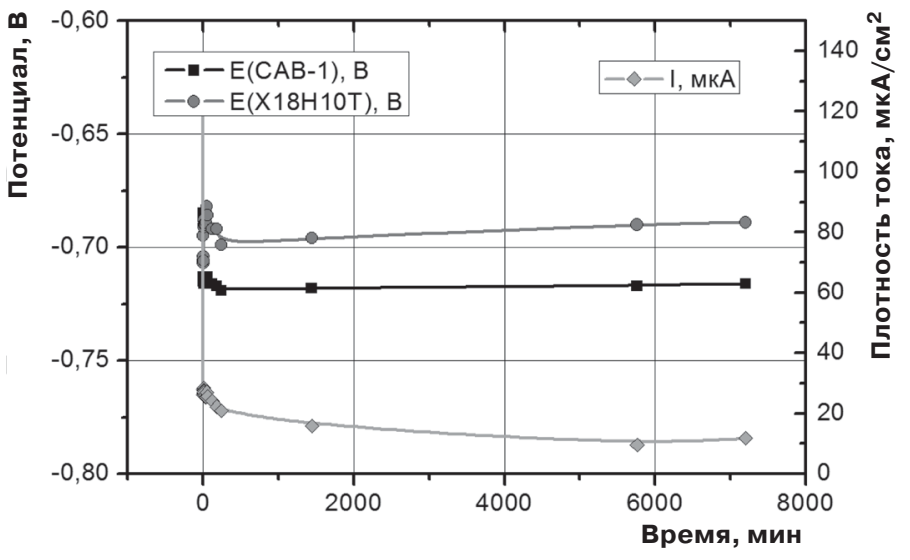

Рис. 2. Зависимость потенциалов и плотности тока коррозии контактной пары САВ-1+X18Н10Т от времени испытания в $3 \%$ растворе $\mathrm{NaCl}$ при $25^{\circ} \mathrm{C}$

коррозии со временем уменьшается, но при этом отличен от нулевого значения (рис. 2). Электрический ток, который протекает в гальванической цепи, имеет большое значение, так как именно он характеризует количественный показатель, описывающий изменение массы образца при коррозии.

Согласно полученным данным, алюминий и сплав CAB-1 с более высоким отрицательным значением стандартного электродного потенциала, окисляясь более интенсивно, чем металл с более низким отрицательным или положительным значением стандартного электродного потенциала и, находясь в контакте с этим металлом, будут служить анодом. Отметим, что один и тот же материал Э110 с неокисленной и окисленной поверхностью имеет разный потенциал:

\section{Материал}

Al CAB-1 X18H10T Э110 Э110 (ок)

Стационарный потенциал

сплавов в $3 \%$ растворе $\mathrm{NaCl}$

при $25{ }^{\circ} \mathrm{C}$ по отношению

к хлор-серебряному

электроду, В*

$\begin{array}{lllll}-1,03 & -0,75 & 0 & -0,5 & +0,05\end{array}$




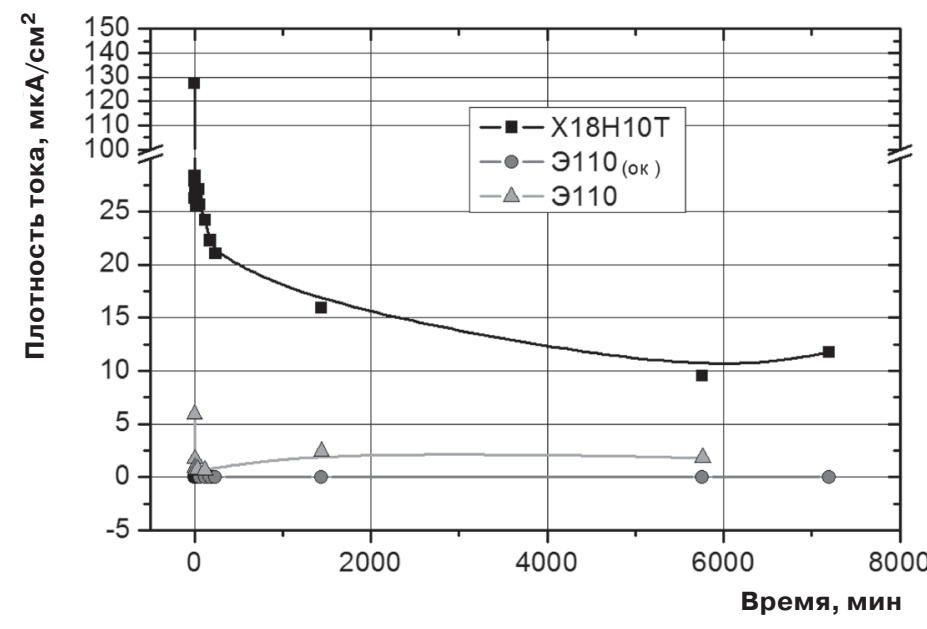

Рис. 3. Зависимость плотности тока коррозии от времени испытания при $25^{\circ} \mathrm{C}$ различных материалов в контакте с САВ-1

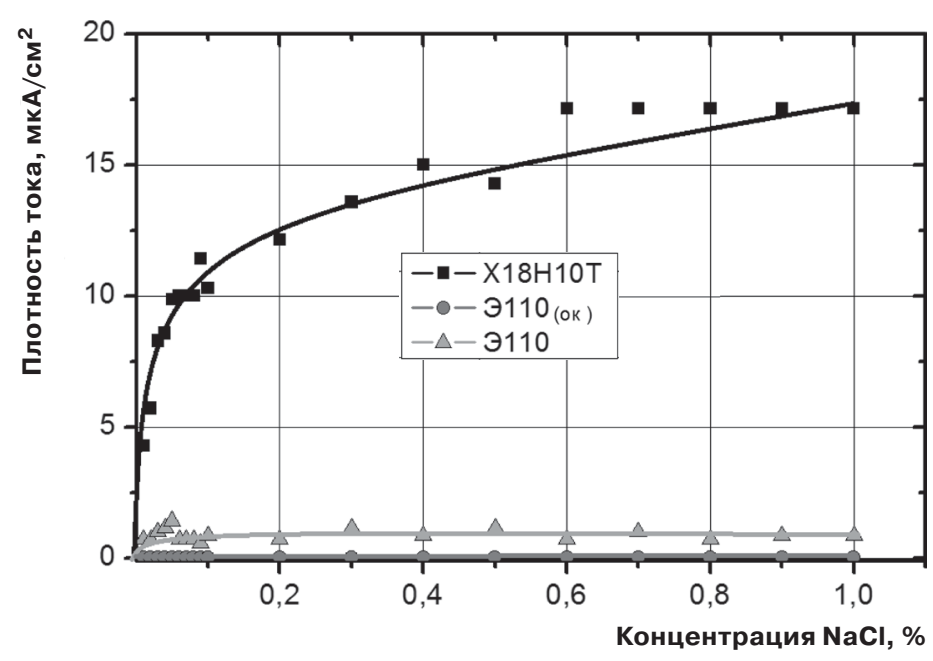

Рис. 4. Зависимость плотности тока коррозии в контактных парах $\mathrm{Al}+\mathrm{X} 18 \mathrm{H} 10 \mathrm{~T}, \mathrm{Al}+Э 110$ и $\mathrm{Al}+Э 110_{(\text {ок) }}$ от концентрации $\mathrm{NaCl}$ при температуре $25^{\circ} \mathrm{C}$

При контакте алюминиевого сплава с нержавеющей сталью плотность тока коррозии наибольшая (табл. 1), соответственно и гальваническая составляющая в общей коррозии алюминиевого сплава будет высокой. При контакте со сплавом Э110, предварительно окисленным $\left(Э 110_{(о к)}\right)$ до толщины оксидной пленки около 5 мкм, ток коррозии в цепи не зафиксирован (рис. 3). Это свидетельствует об отсутствии гальванической коррозии, а значит, и вклад её в общую коррозию алюминиевого сплава в $3 \%$ растворе $\mathrm{NaCl}$ будет пренебрежимо мал.

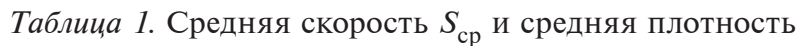
тока $i$ коррозии исследуемых контактных пар при $25^{\circ} \mathrm{C}$

\begin{tabular}{|c|c|c|c|}
\hline \multirow{2}{*}{ Показатель } & \multicolumn{3}{|c|}{ Контактные пары } \\
\hline & CAB-1+X18H10T & САВ-1+Э110 & CAB-1+Э110 (ок) \\
\hline$S_{\text {cp. }}$, мг/(дм².ч) & 1,4 & 0,4 & 0,3 \\
\hline$i, \mathrm{MKA} / \mathrm{cm}^{2}$ & 16 & 1,1 & 0 \\
\hline
\end{tabular}

Так как гальваническая коррозия представляет собой электрохимический процесс, роль электродов в котором играют исследуемые материалы, а коррозионная среда электролит, для которого характерно наличие ионной проводимости, то возникает вопрос о зависимости плотности тока коррозии от чистоты воды.

К интенсивному увеличению плотности тока коррозии приводит повышение концентрации $\mathrm{NaCl}$ до $0,1 \%$. При более высоких концентрациях $\mathrm{NaCl}$ плотность тока увеличивается менее интенсивно (рис. 4).

Кинетика коррозии исследуемых материалов без взаимного контакта. Наиболее высокая скорость коррозии характерна для алюминия. Скорость коррозии алюминиевого сплава CAB-1 немного ниже, а циркониевый сплав Э110 и нержавеющая сталь марки Х18Н10Т практически не окисляются в данных условиях.

При $50{ }^{\circ} \mathrm{C}$, после экспозиции алюминия более $150-$ 200 ч (рис. 5), коррозия алюминия и переход продуктов

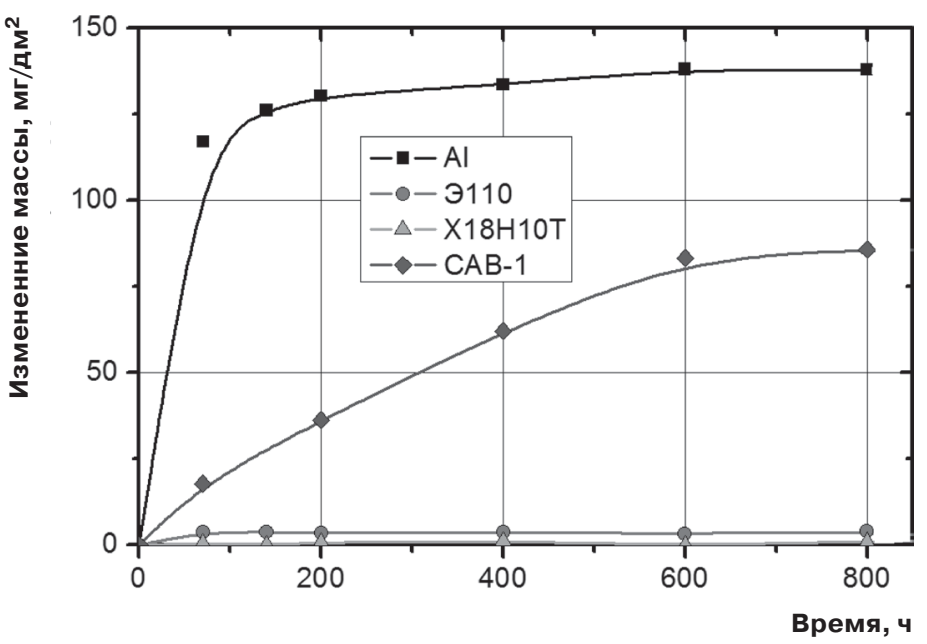

Рис. 5. Зависимость изменения массы образцов $\mathrm{Al}, \mathrm{CAB}-1$, Э110 и Х18Н10Т от времени испытания в химически обессоленной воде с исходной проводимостью 0,25 мкСм/см при температуре $50{ }^{\circ} \mathrm{C}$

его коррозии в коррозионную среду выходят на установившуюся стадию, что на графике зависимости массы образцов от времени описывается практически прямой линией (квазилинейной зависимостью).

Кинетика коррозии исследуемых материалов при их контакте. В случае контакта алюминия с предварительно окисленным циркониевым сплавом $Э 110_{(\text {ок) }}$ скорость коррозии алюминия при температуре $50{ }^{\circ} \mathrm{C}$ практически совпадает со скоростью коррозии алюминия без контакта (рис. 6). При экспозиции более 150 ч скорость коррозии алюминия, полученная по гравиметрическим данным, как без контакта, так и в контактной паре, выходит на одинаковый уровень (параллельные участки на рис. 6).

Исходя из гравиметрических данных, приведенных на рис. 6, может возникнуть ошибочное мнение, что при контакте алюминия с Э110 и Х18Н10Т скорость коррозии алюминия снижается. Однако необходимо учитывать, что при гальванической коррозии процесс окисления сопровождается усиленным переходом продуктов коррозии в коррозионную среду, что, в соответствии с гравиметрическими данными, выражается меньшими привесами (даже по сравнению с тем, когда алюминий без контакта). 


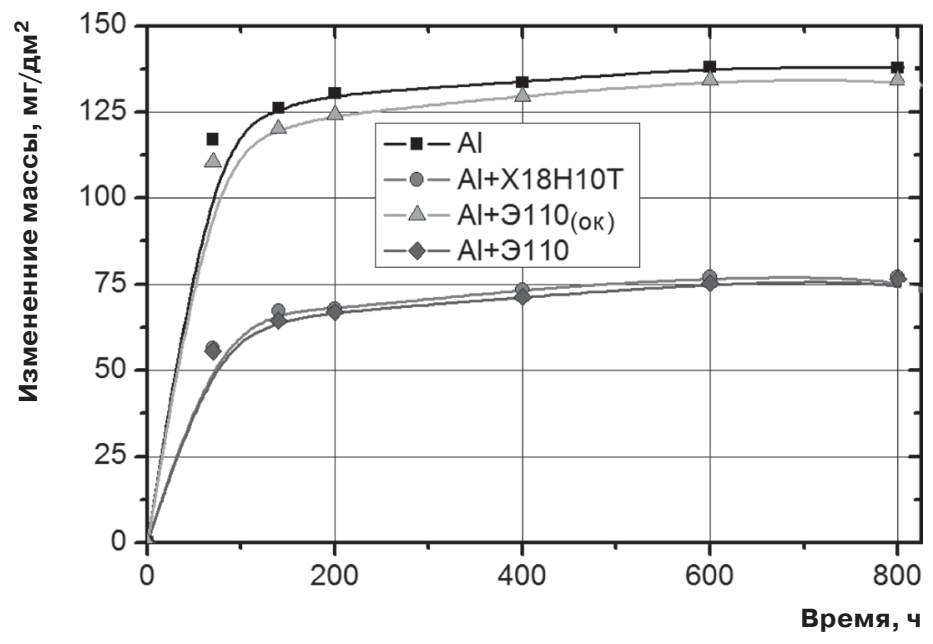

Рис. 6. Зависимость изменения массы образцов А1, Э110, Э110 (ок) и Х18Н10Т в контакте с алюминием от времени испытаний в химически обессоленной воде с исходной проводимостью 0,25 мкСм/см при температуре $50{ }^{\circ} \mathrm{C}$
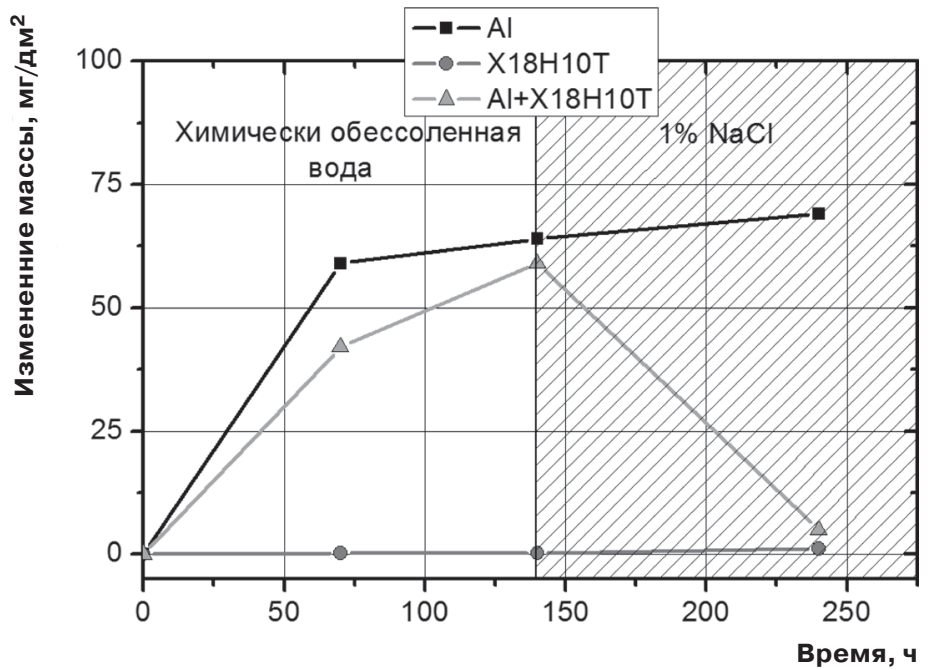

Рис. 7. Зависимости изменения массы образцов Al, X18Н10T и контактной пары $\mathrm{Al}+\mathrm{X} 18 \mathrm{H} 10 \mathrm{~T}$ от времени испытания в химически обессоленной воде с проводимостью 0,25 мкСм/ см и в $1 \%$ растворе $\mathrm{NaCl}$ при температуре $25^{\circ} \mathrm{C}$

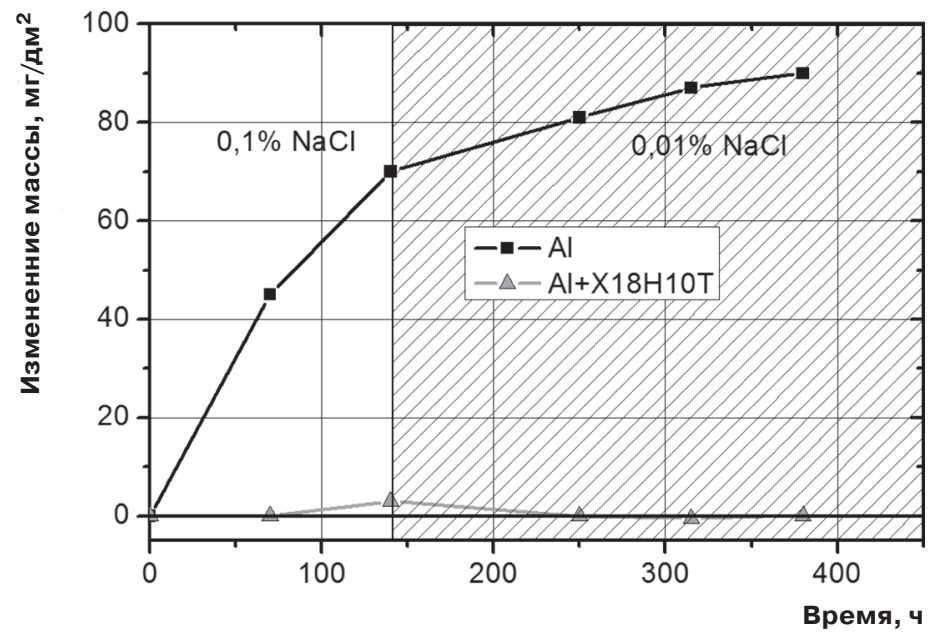

Рис. 8. Зависимости изменения массы образцов $\mathrm{Al}$ и контактной пары $\mathrm{Al}+\mathrm{X} 18 \mathrm{H} 10 \mathrm{~T}$ от времени испытания в водном растворе с $0,1 \% \mathrm{NaCl}$ и в $0,01 \%$ растворе $\mathrm{NaCl}$ при температуре $25{ }^{\circ} \mathrm{C}$
Это доказано дополнительными экспериментами в химически обессоленной воде с добавкой коррозионноактивной примеси $\mathrm{NaCl}$ (рис. 7).

В химически обессоленную воду после 140 ч испытаний добавлен $1 \% \mathrm{NaCl}$. В $1 \%$ растворе $\mathrm{NaCl}$ алюминий без контакта окисляется с увеличением массы (рис. 7), при этом наблюдается значительный переход продуктов коррозии в коррозионную среду, что выражается в присутствии светло-серого осадка на дне сосуда автоклава.

Увеличение массы исследуемых образцов связано с тем, что скорость растворения продуктов коррозии не настолько высока, чтобы полностью компенсировать скорость коррозии. В контактной паре $\mathrm{Al}+\mathrm{X} 18 \mathrm{H} 10 \mathrm{~T}$ этого не наблюдалось. Интенсивное растворение материала анода имело место в средах с добавлением $0,1 \%$ и $0,01 \% \mathrm{NaCl}$ (рис. 8).

Дальнейшие исследования показали, что во всех средах с добавлением $\mathrm{NaCl}$ коррозия контактных пар $\mathrm{Al}+\mathrm{X} 18 \mathrm{H} 10 \mathrm{~T}$ сопровождалась значительным переходом продуктов коррозии в коррозионную среду. Более того, согласно полученным результатам (рис. 7), переход продуктов коррозии в коррозионную среду может происходить как на стадии образования оксида, так и при растворении образовавшейся оксидной пленки.

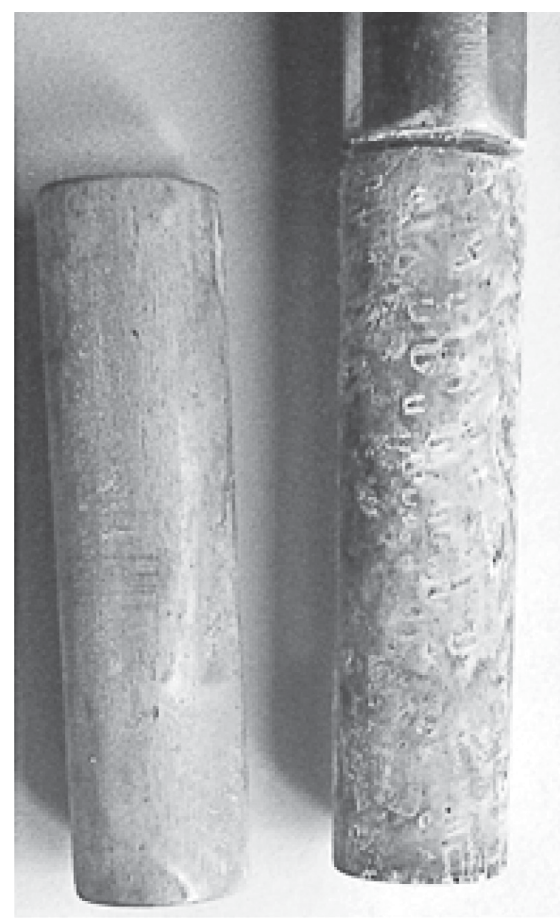

Рис. 9. Внешний вид образцов $\mathrm{Al}$ (слева) и $\mathrm{Al}+\mathrm{X} 18 \mathrm{H} 10 \mathrm{~T}$ (справа) после окисления в $0,01 \%$ $\mathrm{NaCl}$ на протяжении 150 ч

В сосудах, где проходили испытания Al без контакта, переход продуктов минимальный и при малом времени одного цикла экспозиции практически не заметен (не влияет на прозрачность коррозионной среды). Среда после испытаний Al была прозрачной, на дне сосуда не было коллоидного осадка.

На образце контактной пары Аl+X18Н10T присутствуют многочисленные локальные коррозионные проявления - питтинги (рис. 9). 
Выбор оптимальной толщины защитной оксидной пленки на Э110 для использования в контакте с САВ-1 в водной среде. Как известно, скорость растворения анода зависит от разности потенциалов между катодом и анодом и определяется плотностью тока коррозии. При уменьшении плотности тока коррозии снижается влияние гальванической составляющей в процессе коррозии анода (CAB-1).

Для выбора оптимальной толщины оксидной пленки на катоде (циркониевый сплав Э110) были изготовлены образцы с толщиной оксидной пленки от 0 до 1,8 мкм, после чего - контактные пары САВ-1+Э110 (ок)

В начале испытания при контакте CAB-1 с Э110 плотность тока коррозии имеет наибольшее значение. Со временем испытания его значение уменышается до стационарного (рис. 10). При контакте САВ-1 и неокисленного Э110 плотность тока коррозии наибольшая. Предварительное окисление Э110 приводит к снижению скорости коррозии САВ-1 в контактной паре. Для определения влияния толщины оксидной пленки катода (Э110) на скорость коррозии анода (CAB-1) в контактной паре

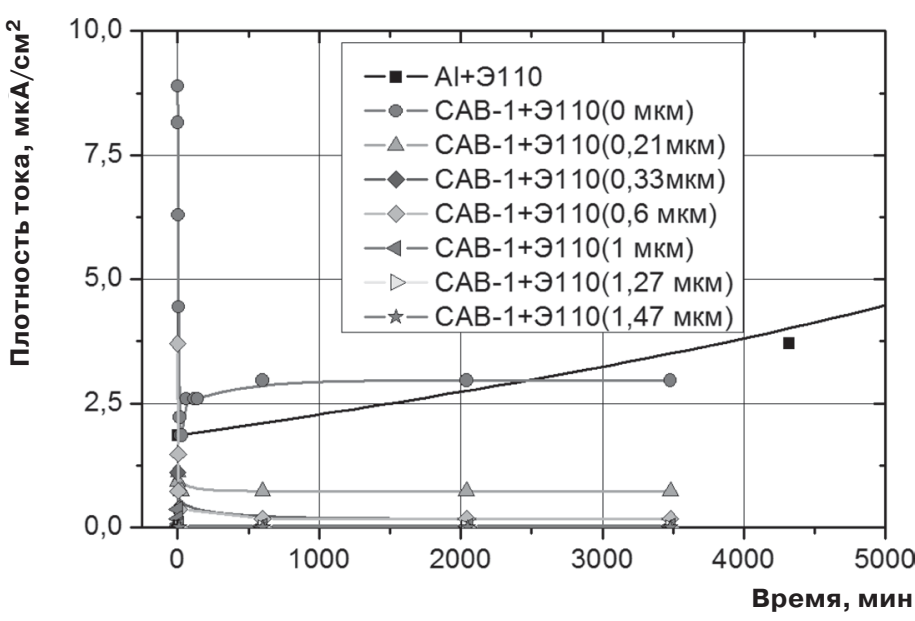

Рис. 10. Зависимость плотности тока коррозии контактной пары САВ-1+Э110 от времени испытаний в $1 \%$ растворе $\mathrm{NaCl}$ при температуре $25{ }^{\circ} \mathrm{C}$

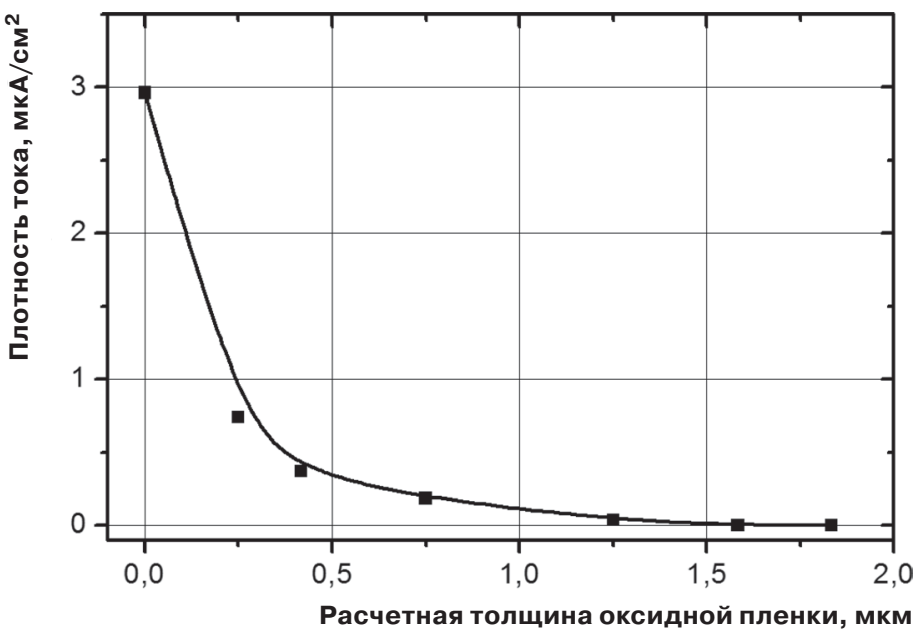

Рис. 11. Зависимость плотности тока коррозии контактных пар САВ-1+Э110 от толщины оксидной пленки на Э110 в $1 \%$ водном растворе $\mathrm{NaCl}$ при температуре $25{ }^{\circ} \mathrm{C}$

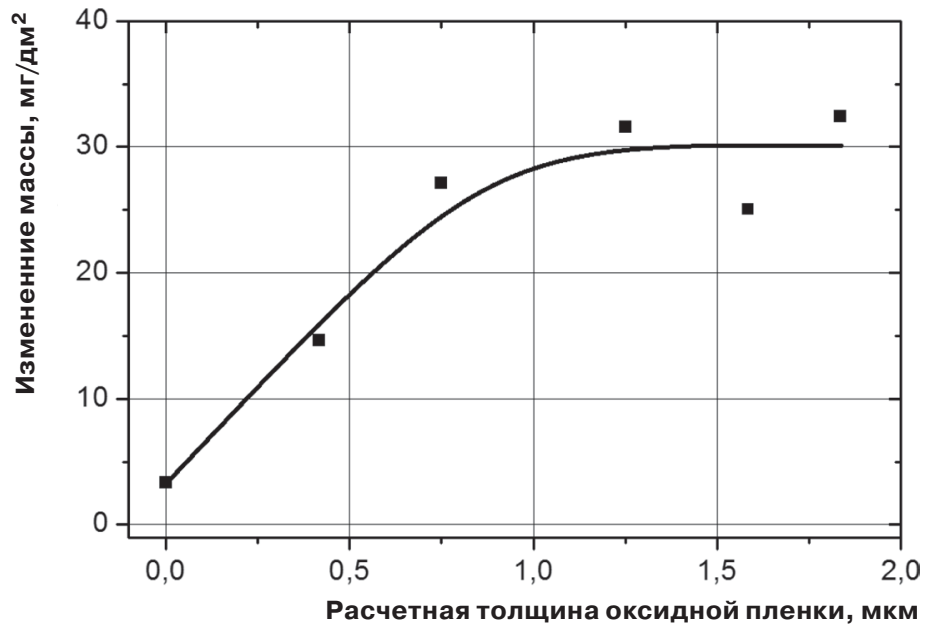

Рис. 12. Изменение массы образцов САВ-1+Э110 с разной толщиной оксидной пленки в зависимости от времени испытания в химически обессоленной воде с исходной проводимостью 0,25 мкСм/см при $50{ }^{\circ} \mathrm{C}$

построена зависимость плотности стационарного тока коррозии от расчетной толщины оксидной пленки на катоде (рис. 11).

Плотность тока коррозии наибольшая при контакте сплава САВ-1 с неокисленным сплавом Э110 (рис. 11). С увеличением толщины оксидной пленки на сплаве Э110 плотность тока коррозии уменьшается. При толщине оксидной пленки 1-1,5 мкм плотность тока невозможно зафиксировать измерительными приборами, которые использовались в данном исследовании.

Из полученных результатов следует, что предварительное окисление материала катода (Э110) до толщины оксидной пленки 1-1,5 мкм почти полностью исключает гальваническую составляющую коррозии сплава САВ-1 в контактной паре САВ-1+Э110.

Также проведены автоклавные испытания указанных контактных пар в химически обессоленной воде (рис. 12), причем показателем коррозии является изменение массы образцов сплава САВ-1.

Наименьший привес фиксировался на САВ-1 в контакте с неокисленным Э110 (рис. 12). С увеличением толщины оксидной пленки на Э110 привес на САВ-1 увеличивается. При достижении толщины оксидной пленки 1-1,5 мкм на Э110 привес САВ-1 практически не отличается от привеса при коррозии САВ-1 без контакта. Следовательно, предварительное окисление материала катода (Э110) до толщины оксидной пленки 1-1,5 мкм практически исключает гальваническую составляющую коррозии САВ-1 в контактной паре САВ-1+Э110, что совпадает с результатами измерения плотности тока коррозии.

\section{Обсуждение результатов}

Анализ результатов исследований и систематизация литературных данных показывают, что совместимость конструкционных материалов ядерных установок, таких как алюминий или его сплавы с цирконием и нержавеющей сталью, в значительной степени определяется электрохимической (контактной или гальванической) коррозией. 
В данной работе для образцов исследуемых нами материалов (Al, САВ-1, Э110, Х18Н10Т) с механически полированной поверхностью определен стационарный потенциал в $3 \%$ растворе $\mathrm{NaCl}$ при $25{ }^{\circ} \mathrm{C}$ по отношению к хлорсеребряному электроду сравнения. Исходя из полученных данных, в воде при контакте алюминия и алюминиевого сплава CAB-1 с нержавеющей сталью и циркониевым сплавом Э110 анодом служит алюминий (и сплав САВ-1), и он будет окисляться значительно быстрее, а катодом нержавеющая сталь или сплав Э110. Контактная пара $\mathrm{Al}+Э 110_{(\text {ок) }}$ имеет большую разность потенциалов, и, соответственно, должна быть более склонна к контактной коррозии, но результаты проведенных экспериментов указывают на обратное.

Гальванический потенциал является характеристикой склонности металлов (сплавов) к гальванической коррозии, при этом важна также информация о плотности электрического тока, протекающего между разнородными металлами (сплавами) [7].

Результаты измерения плотности тока коррозии (рис. 3, табл. 1) показали, что несмотря на самую большую разность потенциалов для контактной пары САВ-1+Э110 (ок) плотность тока коррозии настолько мала, что ее невозможно зафиксировать доступными измерительными приборами Соответственно, и гальваническая составляющая в общей коррозии САВ-1 будет пренебрежимо мала. Контакт CAB-1 с нержавеющей сталью в водной среде вызывает более интенсивную коррозию анода, чем его контакт со сплавом Э110. Плотность тока коррозии для контактной пары САВ-1+X18Н10T составляет $16 \mathrm{MKA} / \mathrm{cm}^{2}$, а для САВ-1+Э110 - 1 мкA/ см$^{2}$. Следовательно, в ядерных установках, где неизбежен контакт разнородных материалов, предпочтительнее использовать циркониевый сплав Э110, а не нержавеющую сталь.

Согласно результатам проведенных исследований, коррозия алюминия и его сплавов без контакта и в контакте очень чувствительна к составу коррозионной среды. В химически обессоленной воде с проводимостью 0,25 мкСм/см вклад гальванической составляющей в общую коррозию алюминиевого сплава незначителен. С ухудшением качества воды (при добавке коррозионно активных примесей в воду около $0,01 \% \mathrm{NaCl})$ преобладает гальваническая составляющая коррозии. Коррозия в такой среде протекает с образованием питтингов.

Однако, несмотря на столь малую плотность тока коррозии для контактной пары САВ-1+Э110, гальваническая составляющая коррозии присутствует. Исходя из имеющихся литературных сведений, контакт алюминиевого сплава с циркониевым сплавом в водной среде вызывает два негативных явления: гальваническую коррозию, которая сопровождается ускоренным растворением алюминиевого сплава, и катодное гидрирование циркониевого сплава [3-5]. Чтобы избежать этого, необходимо либо использовать чистую воду, что в ядерных установках открытого типа не всегда возможно, либо электрически разделить разнородные материалы нетокопроводящим (изолирующим) материалом.

Проведенные исследования показали, что при испытании контактных пар САВ-1+Э110 наличие на образце Э110 оксидной пленки приводит к снижению плотности тока коррозии до нуля, а исходя из гравиметрических данных, полученных при автоклавных испытаниях, скорость коррозии САВ-1 в контакте с Э110 (ок) коррозии САВ-1 без контакта.
Определена минимальная толщина оксидной пленки на сплаве Э110, которая позволяет минимизировать гальваническую коррозию. Экспериментальные данные, полученные при автоклавных коррозионных испытаниях контактных пар в химически обессоленной воде при температуре $50{ }^{\circ} \mathrm{C}$, указывают на то, что предварительное окисление материала катода (сплава Э110) до толщины оксидной пленки 1-1,5 мкм практически исключает гальваническую составляющую коррозии САВ-1 в контактной паре САВ-1+Э110, что совпадает с результатами измерения плотности тока коррозии.

\section{Выводы}

1. При проведении электрохимических и автоклавных испытаний алюминия и его сплава САВ-1 в контакте с циркониевым сплавом Э110 и нержавеющей сталью марки Х18Н10Т показано, что во всех случаях анодом является алюминий или САВ-1, который окисляется более интенсивно. При коррозии алюминия и САВ-1 в водной среде продукты коррозии переходят в коррозионную среду.

2. Результаты электрохимических исследований указывают на наличие тока коррозии в контактных парах САВ-1+Х18Н10Т и САВ-1+Э110. Плотность тока коррозии составляет около 16 и 1 мкA/ $\mathrm{cm}^{2}$ соответственно, что свидетельствует о протекании гальванической коррозии. Следовательно, в ядерных установках, где неизбежен контакт разнородных материалов, предпочтительнее использовать циркониевый сплав Э110, а не нержавеющую сталь. В контактной паре САВ-1 с предварительно окисленным Э110 ток коррозии настолько мал, что его невозможно зафиксировать измерительными приборами. Предварительное окисление материала катода (сплава Э110) позволило минимизировать или даже исключить гальваническую составляющую коррозии (САВ-1 уже не будет играть роль интенсивно растворяющегося анода) в течение длительного времени эксплуатации в водном теплоносителе. Предварительное окисление сплава Э110 позволило сохранить его устойчивое пассивное состояние при отклонениях разного уровня от основных показателей качества водного теплоносителя.

3. На основании экспериментальных данных, полученных при автоклавировании контактных пар в химически обессоленной воде при температуре $50{ }^{\circ} \mathrm{C}$, можно утверждать, что предварительное окисление материала катода (сплава Э110) до толщины $1-1,5$ мкм практически исключает гальваническую составляющую коррозии CAB-1 в контактной паре САВ-1+Э110. Это утверждение совпадает с результатами измерения плотности тока коррозии.

4. Использование алюминиевого сплава САВ-1 в контакте с циркониевом сплавом Э110 в водной среде без значительного увеличения скорости коррозии САВ-1 возможно только в химически обессоленной воде с низкой электрической проводимостью. В случае использования среды с более высокой электрической проводимостью необходимо электрически разделить разнородные материалы нетокопроводящим (изолирующим) материалом или на один из материалов нанести защитное покрытие, которое не позволит гальваническому току проходить через коррозионную среду. 


\section{Список использованной литературы}

1. Revie, R. W. (editor). (2011), Uhlig's corrosion handbook. 3rd ed John Wiley \& Sons, Inc., Hoboken, New Jersey, 1296 p.

2. Davis, J.R. (editor). (2000), Corrosion: Understanding the basics. ASM International, Materials Park, Ohio, $563 \mathrm{p}$.

3. IAEA-TECDOC-1343. (2003), Spent fuel performance assessment and research. Final report of a Coordinated Research Project on Spent Fuel Performance Assessment and Research (SPAR) 1997-2001. IAEA, Vienna, 123 p.

4. IAEA-TECDOC-1012, (1998), Durability of spent nuclear fuels and facility components in wet storage. IAEA, Vienna, $91 \mathrm{p}$.

5. Johnson, A.B., (1977), «Behaviour of Spent Nuclear Fuel in Water Pool Storage», PNL, Technical Report BNWL-2256 UC70, Richland, Washington.

6. Bratsch, S.G. (1989), «Standard electrode potential and temperature coefficients in water at $298.15 \mathrm{K»}$, Journal of Physical and Chemical Reference Data, vol. 18, № 1, pp. 1-21.

7. Cheremisinoff, N.P., (1996), Materials selection deskbook, Noyes Publications, New Jersey, $191 \mathrm{p}$.

\section{References}

1. Revie, R.W. (editor), (2011), "Uhlig's Corrosion Handbook". 3rd ed. John Wiley \& Sons, Inc., Hoboken, New Jersey, 1296 p.

2. Davis, J.R. (editor), (2000), "Corrosion: Understanding the Basics". ASM International, Materials Park, Ohio, 563 p.
3. IAEA-TECDOC-1343. (2003), "Spent Fuel Performance Assessment and Research". Final Report of a Coordinated Research Project on Spent Fuel Performance Assessment and Research (SPAR) 1997-2001. IAEA, Vienna, $123 \mathrm{p}$.

4. IAEA-TECDOC-1012, (1998), "Durability of Spent Nuclear Fuels and Facility Components in Wet Storage". IAEA, Vienna, 91 p. 5. Johnson, A.B., (1977), "Behaviour of Spent Nuclear Fuel in Water Pool Storage", PNL, Technical Report BNWL-2256 UC70, Richland, Washington, $104 \mathrm{p}$

6. Bratsch, S.G. (1989), "Standard Electrode Potential and Temperature Coefficients in Water at 298.15 K", Journal of Physical and Chemical Reference Data, vol. 18, No. 1, pp. 1-21.

7. Cheremisinoff, N.P., (1996), "Materials Selection Deskbook", Noyes Publications, New Jersey, 191 p. 